\title{
Analyze Instrument for Improved Visualization Creativity In Learning Physics With Matlab Software Using PjBL and KWL
}

\author{
Satria Mihardi \\ State University of Medan \\ Wawan Bunawan \\ State University of Medan \\ Sahyar \\ State University of Medan
}

\begin{abstract}
The purpose of this research is intended to improve the creativity of students in the products with a visualization of the equations of physics in learning by using projectbased learning model and getting standardized assessment instrument in the assessment of student creativity that is specific to each indicator creativity. Model of project-based learning is an instructional model that can enhance the creativity of students through activities in learning syntax. To achieve an increase in creativity, then, the lesson is designed to be able to attract students thinking skills to a high level. Learning that can improve creativity one of which is learning by PjBL Model. By using the PjBL model students in learning activities that match the syntax. The PPA will be able to increase creativity. In addition, the use of KWL then planning the achievement of a product as a result of creativity will be more focused and systematic. So that the achievement of a product which is expected to be more effective and efficient. Research conducted at the FMIPA Unimed. The type of research conducted an action research aimed to see an increase in student creativity. To see an increase in the use of data analysis to test $\mathrm{N}$-Gain. In the implementation of the research conducted in the cycle consists of four actions in one cycle.
\end{abstract}

Keywords: Creativity, Project Based Learning Model, KWL

\section{INTRODUCTION}

In achieving the ASEAN Economic Community (MEA), State University of Medan (Unimed) as one of the universities in Indonesia participated in preparing the competence and ability of human. It is intended that the younger generations are able to compete and participate in the development of Science, Technology and the Arts (IPTEKS) in relationships internationally. Various attempts were made in order to prepare for the Indonesian people to be able to be one of the competitors in the International competition. Supporting these objectives, Unimed make adjustments in improving the competence of graduates, the learning process, and strategic planning (strategic planning) in accordance with the National Qualifications Framework Indonesia (KKNI). Repairs are carried out continuously directed the students based on the liveliness and character formation of students. In addition, Unimed also provide motivation and full support to the entire faculty to be able to continue to improve the competence, educational and scientific works of international standard.

In reality, the process of learning that takes place is not as expected. There are still many shortcomings of the learning process needs to be improved to be able to reach the MEA. It can be seen from some of the learning process and assessment learning outcomes, where the 
student activities are concentrated on the task completion and fulfillment of college attendance. This affects the students to be creative and not be burdened on the tasks given. In addition, the results of the task of optimizing the students do not show both individually and collectively. This is because the students just think to accomplish a given task than do the analysis of what is given. Another factor that is also a reason not develop the creativity of students is the use of models/learning methods that are less precise and instruments provided to students still can not lead students to be able to achieve creativity.

Awang \& Ramly (2008) said that creative thinking can be done by making some choices settlement obtained from different perceptions, different concepts, different points of view in order to vary the settlement method. In addition, Mukhopadhyay, R., (2013) explained that is true particularly in case of a Test on Creativity in Physics, for psychometric construct of creativity in physics being critical, as well as multidimensional. This is also confirmed of research Neira, J.A.P \& Soto, I.R.S. (2013) said that the high correlation between some dimensions of creativity and academic success, indicates the importance of this cognitive variable (creativity) in the teaching and learning science, so it is urgent to consider it at the moment of building intervention methods in the classroom. Thus, students will be considered successful if it has the ability to create on to apply the knowledge they received.

On the application of PjBL Model on research Hong, L., Yam, S. \& Rossini, P., (2010) states that $\mathrm{PjBL}$ is a significant approach in enhancing the potential of changing the way teaching and learning is passive to enable Students with the tools and media support to improving learning outcomes. According Holubova (2008) PjBL has advantages in this type of teaching on Student activities and opportunities to solve multidisciplinary problems. This is confirmed ChanLin (2008) which states that it is important to do PjBL implementation by integrating technology in learning as Students planning on the experience of self-exploration. This is done because according to Nurohman (2008) have PjBL stages of learning that is consistent with scientists methods, so as to facilitate the internalization of values and spirit of the methods scientists to Students. It shows that PjBL model can also be associated with the technology to further enhance the creative product.

Nani, K. L. \& Kusumah, Y. S. (2015) said that learning process were concluded that ICT assisted project-based learning is effective in enhancing student's statistical communication ability. This is confirmed by research of Moraru, S., Stoica, I., \& Popescu, F. F., (2011) were provide much more effective and efficient environments in teaching and learning, making physicsscience easier to understand. It is generally acceptable that the use of interactive teaching tools, which provide instant feedback to the student's inputs, improve and accelerate the learning process. By using educational software, the student is provided with sequences, which can be lesson stages, tests, and so on. Through these sequences, he or she can access information (libraries, internet), can receive a mark, or can contact other students who work in the same environment. Mihardi, S., Harahap, M.B., \& Sani, R.A (2013) said that Project Based Learning actually effective to advance Student creative thinking process. This is due, in the activities of PjBL allows students to be prosecuted and trained to produce a product. This is confirmed by Banaji, S., Perrotta, C., \& Cranmer, S., (2010) The good practices in relation to innovative teaching and creative learning embodied in the ten examples provided here are not the only ones we found during our investigation of creativity and innovation. Based on consideration of the studies the planned study on increase creativity of students in PjBL models by optimizing the use of technology in learning. Thus, it is clear that the use of PjBL model with media technology will be able to more effectively deliver the output in the form of creativity to students. 
In the learning, PjBL model has been contributed components like as learner-centered environment, collaboration, curricular content, authentic tasks, multiple expression modes, emphasis on time management, and innovative assessment. According Baker, E., Trygg, B., Otto, P., Tudor, M. \& Ferguson, L., (2011) said that Project-Based Learning Model engages students in relevant learning that positively impacts their local communities and ecosystems. Teachers or mentors facilitate, rather than direct, students as Student explore a system, ask questions, look at problems within that system, determine solutions, plan and ultimately implement a project. According Nani, K.L \& Kusumah, Y.S. (2015) that Project-based learning (PjBL) is learning model which gives opportunity to teachers to manage in class by involving project work. PjBL which is integrated with information and community technology (ICT) aims to provide opportunity to students to learn introductory statistic by using authentic problem project. The application of ICT assisted PjBL is said effective in enhancing student's statistical communication ability.

Cakmakci \& Tasar (2010) explained that in the project based learning perspective, learning is dealt with the reorganization of the cognitive structure of the learner. Another thing explained Thomas (2000) that there are a number of ways that research on student characteristics in PjBL can be conducted. Alternatively, PjBL designs or features in order to adapt to (accommodate, remediate) student characteristic variables. There are a number of student characteristic variables that might be investigated in the context of Project-Based Learning at five critical thinking behaviors (synthesizing, forecasting, producing, evaluating, and reflecting) and five social participation behaviors (working together, initiating, managing, inter-group awareness, and inter-group initiating). According Jones, J \& Monco, J. (2015) said when employing true project-based design, choice of project is critical. Typical projects present a problem to solve (a necessity in problem-based learning), a phenomenon to investigate, a model to design, or a make decision.

According Ogle (1986) that the KWL (Know, Want, Learn) strategy provides a structure for activitating and building prior knowledge, establishing a purpose for reading and for summarising what was learned. According Al-Khateeb \& Idrees (2010) that the dependence of the KWL strategy on presenting the teaching content correspondently with the logical organization of the content, which is based on gradual advance from the easy to the more difficult, supported the learning process of the experiment group to learn the religious concepts and acquire the abilities of classification, construction and evaluation; since all depend on highleveled thinking processes. Using KWL strategy in teaching added the element of interaction, represented in the experiment group members' participation (during different stages of the teaching process) in collecting what Student know about the topic; then, what Student want to know about it; then, writing all new information Student have learned about this particular topic. In Otherwise, KWL (Ogle, 1986) takes students through the entire comprehension process, including preparation for reading and processing of text during reading.

According Richardson (2012) that for using KWL chart will be applied in class with following fourth steps below:

Step 1: Choose a general topic and create a table with three columns and two rows - one row for the headings and one large in which to write. Label the first column with a $\mathbf{K}$ for "What I Know," the second with a W for "What I Want to know," and the third with an L for "What I Learned" or a variation of this. Introduce the KWL strategy and model how to use it with the topic.

Step 2: As a class group brainstorm what students already know about a specific subject topic. Highlight the importance of prior learning and how life experience and making connections to 
what we already know is a very important part of learning. Write these ideas under the $\mathbf{K}$ column.

Step 3: Now have students generate a list of what else Student want to learn or questions Student want answered. Continue to demonstrate how to organize and categorize their suggestions and how to use this information to set a purpose for reading. Students can also turn textbook headings and subheadings into questions for the $\mathbf{W}$ column. Students now read (or listen) the text and actively look for answers to their questions as well as to verify their knowledge.

Step 4: After reading with purpose Student discuss and record what Student learned in the $\mathbf{L}$ column, especially paying attention to $\mathbf{W}$ questions that were answered from the text or activity. Provide multiple opportunities for students to use the strategy in pairs or small groups until Student can use the strategy independently. The L column can also serve as notes for review and revision.

A creative thinking is a thinking processed in Anderson dimension. The creative thinking is the power level of thinking that is natural talent of individuals in solving some of the problems (Sternberg \& Lubart, (1995) and Mokaram, A. K., Al-Shabatat, A. M., Foong, F. S. \& Abdallah, A. A., (2011)). In addition, Young (1990) was also described as the combination of divergent and convergent thinking. The same defined is explained Kirton (1987) that was defined as the combination of the both. A viewed theoretically, the divergent thinking seems to involve the generation of alternatives and unique ideas in the thinking process, whereas convergent thinking involves selecting ideas based on their uniqueness, feasibility, and quality. This is confirmed also according Kim (2008) based explain from research of Guilford (1950, 1962, 1966, 1968) which hypothesized that creative individuals possess divergent thinking abilities including idea production, fluency, flexibility, and originality. Creativity and creative thinking fare no greater under Ausubel's analysis. Genuine creativity as so rare that it is not worth pursuing in most educational contexts, where it is more democratic to use available resources to cater for the needs of the many rather than the few.

\section{METHOD}

The design of this action research in the form of a cycle. In one cycle has four phases that aims to optimize the evaluation of the actions in the study. For each one cycle is done every 4 meeting. In one cycle will be 4 stages of completion. This stage aims to facilitate the activities carried out so that a more systematic and coordinated so that the objectives of the research can be achieved effectively and efficiently. Stages are:

Stages 1: Process Planning, is made to be able to design activities and documents to be used in research. This activity is carried out by the research team with the aim of activities carried out can be coordination in the division of tasks and roles of each member of the research team. Things are done in these stages are: Designing SAP and RKPS, Instrument Design Assessment, Design Project, and the Division of Research Team.

Stages 2: Pre-Preliminary process, undertaken to facilitate the implementation of research activities in order to more activity in terms of implementation coordination has done. At this stage, members of the research team to simulate and share the stage role as the prevention and control in order to avoid bias in the research. At this stage, members of the research team must understand the role of every gift given work. At this stage of research subjects also determined that the research sample. Things that do are: Simulation of activities, Determination of research samples, Finalize Document and Instrument Learning. 
Stages 3: Implementation, at this stage, the learning process and data collection. The implementation process was conducted during 8 meetings effective learning. Data collected in the form of observation, video, product and test results. This stage is adjusted to the schedule of lectures on the subject are planned.

Stages 4: Evaluate, at this stage of data collection results are analyzed and reported as a research report on the implementation of that has been done during the learning. At this stage also carried out an evaluation of the activities carried out to be able to continue to develop and improve the quality of learning that has taken place.

\section{RESULTS}

From the results of the implementation of the first cycle obtained a description of the results of use instrument that was tested on a sample of self-assessment according to Figure 1.

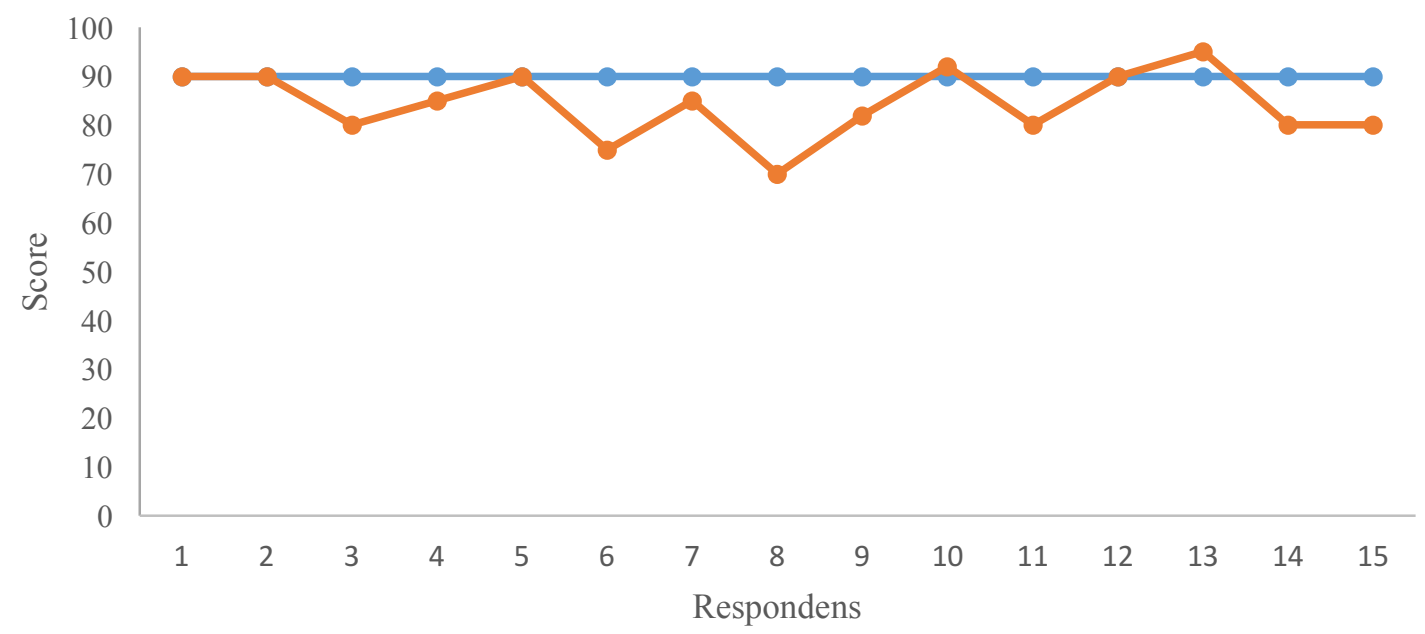

Figure 1. Interpretation in First Cycle

The results of the use of the instruments on posttest show on a small sample is not too significant improvement compared with the expected goals. However, the application of a significant instrument in the self-assessment with evidence of activity sheet. This is because the use of the instrument was never used and became a new thing for the study sample in providing self-assessment for himself or members of his group. Despite such gaps in the assessment is not too significant deviation occurs due to lack of the habit of a factor in the assessment of honesty.

In the second cycle of use instrument showed a significant increase when compared with the cycle I. This is because in its use in the assessment of the suitability of individual and peerevaluation. Overview of the use of instruments in the second cycle shown in Figure 2.

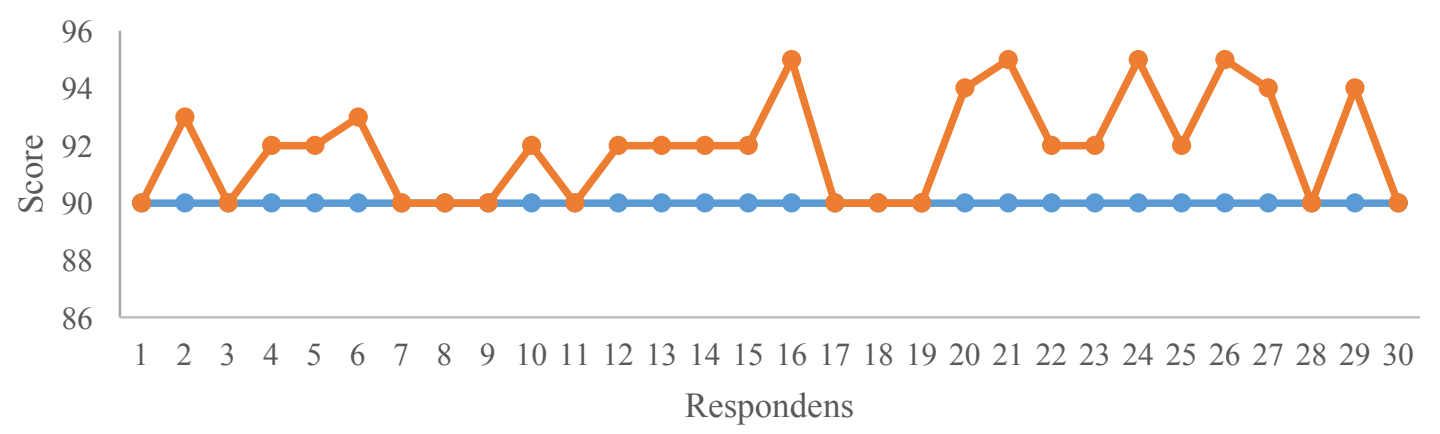

Figure 2. Interpretation Instrument in Second Cycle 
The results of the use of the instruments on posttest showed an increase in the sample than the pretest. The assessment is significant to the achievement of the information passing between video evidence and self-assessment are used as assessment instruments. With the motivating factors such as videos, photos, and report the performance of the valuation performed more shows awareness of honesty in their assessments, so that the results are very significant support for the development and the expected results.

\section{CONCLUSION}

From this study it can be concluded that the resulting self-assessment instruments can be clearly demonstrated that ratings significantly between the self-assessment to the assessment of the team in delivering products on project planning. Self-assessment helps Students develop character judgments on themselves both in learning and in developing learning skills.

\section{References}

Al-Khateeb, O. S. M. \& Idrees, M. W. K. (2010). The Impact of Using KWL Strategy on Grade Ten Female Students' Reading Comprehension of Religious Concepts in Ma'an City. European Journal of Social Sciences - Volume 12, Number 3 (2010). Taibah University, Kingdom of Saudi Arabia.

Awang, H. \& Ramly, I. (2008). Creative Thinking Skill Approach Through Problem-Based Learning: Pedagogy and Practice in the Engineering Classroom. International Journal of Human and Social Sciences 3:1, 2008.

Baker, E., Trygg, B., Otto, P., Tudor, M. \& Ferguson, L. (2011). Project-Based Learning Model Relevant Learning For The $21^{\text {st }}$ Century. Pacific Education Institute, www.pacificeducationinstitute.org.

Banaji, S., Perrotta, C., \& Cranmer, S., (2010). Creative and Innovative Good Practices in Compulsory Education in Europe, Collection and Descriptive Analysis of 10 Good Practices of Creativity and Innovation in Compulsory Education in the EU27, JRC Technical Notes

Buck Institute for Education, (2010). Project Based Learning Handbook: A Guide to Standards-Focused Project Based Learning, Second Edition. The Buck Institutes for Education's Handbook for Project Based Learning. Retrieved July 15, 2010. Accessed in http://www.bie.org/index.php/site/PBL/pbl_handbook/

Cakmakci, G. \& Tasar, M. F. (2010). Contemporary Science Education Research: Learning And Assessment A Collection Of Papers Presented At ESERA 2009 Conference. ISBN 9786053640332 (C) Copyright ESERA, 2010.

ChanLin, L. J. 2008. Technology Integration Applied to Project-Based Learning In Science. Department of Library \& Information Science, Fu-Jen Catholic University, Hsin-Chuang, Taiwan. Innovations In Education And Teaching International. Vol. 45, no. 1, February 2008, 55-65. Email: lins1005@mails.fju.edu.tw. ISSN 1470-3297 (C) 2008 Taylor \& Francis. Http://www.informaworld.com.

Guilford, J. P. (1950). Creativity. American Psychologist, 5, 444-454.

Guilford, J. P. (1962). Creativity: Its Measurement And Development. In J. J. Parnes and H. F. Harding (eds.) $A$ Source Book For Creative Thinking. NewYork: Scribners.

Guilford, J. P. (1966). Intelligence: 1965 Model. American Psychologist, 21, 20-26.

Guilford, J. P. (1968). Intelligence, Creativity, and Their Educational Implications. San Diego, CA: Robert R. Knapp. Guilford JP. Creativity. Am Psychol 1950; 5: 444-54.

Hake \& Richard, R. 2002. Relationship of Individual Student Normalized Learning Gains in Mechanics with Gender, High-School Physics, and Pretest Scores on Mathematics and Spatial Visualization. Downloaded in http://www.physics.indiana.edu/ hake. Accessed on 15 March 2013.

Heo, H., Lim, K. Y. \& Kim, Y. (2010). Exploratory Study On The Patterns of Online Interaction And Knowledge CoConstruction In Project-Based Learning. Computers \& Education Journal Homepage: www.elsevier.com/locate/compedu

Holubova, R. 2008. Effective Teaching Methods-Project-Based Learning In Physics. Faculty of Science, Palacky University Olomouc, Svobody 2677146, Czech Republic. Dec. 2008, volume 5, no.12 (serial no.49). Us- China Education Review, ISSN 1548-6613, USA.

Hong, L., Yam, S. \& Rossini, P. 2010. Implementing A Project-Based Learning Approach In An Introductory Property Course. 16th Pacific Rim Real Estate Society Conference Wellington, New Zealand, January 2010. University of South Australia. 
Jones, J \& Monco, J. 2015. Problem Based-Learning / Project Based-Learning. Journal of Learning Architects Product Strategy, Innovation and Development.

Kim, K. G. (2008). Meta-Analyses of The Relationship of Creative Achievement To Both IQ And Divergent Thinking Test Scores. Volume 42 Number 2 Second Quarter 2008.

Kirton, M. (1987). Adaptors and Innovators: Cognitive Style And Personality. In S.G. Isaksen (Eds). Frontiers of Creativity Research: Beyond The Basics. Buffallo, NY: Bearly Limited.

Mihardi, S., Harahap, M.B., \& Sani, R.A (2013). The Effect of Project Based Learning Model with KWL Worksheet on Student Creative Thinking Process in Physics Problems. Journal of Education and Practice, Vol.4, No.25, 2013. ISSN 2222-1735 (Paper) ISSN 2222-288X (Online).www.iiste.org or jep@iiste.org

Mokaram, A. K., Al-Shabatat, A. M., Foong, F. S. \& Abdallah, A. A. (2011). Enhancing Creative Thinking through Designing Electronic Slides. International Education Studies Vol. 4, No. 1; February 2011 Published by Canadian Center of Science and Education 39. Http:// www.ccsenet.org/ies.

Mukhopadhyay, R., (2013), Measurement of Creativity in Physics - A Brief Review on Related Tools IOSR Journal Of Humanities And Social Science (IOSR-JHSS), ISSN: 2279-0837, ISBN: 2279-0845, Volume 6, Issue 5 (Jan. - Feb.2013), PP 45-50 www.Iosrjournals.Org.

Moraru, S., Stoica, I., \& Popescu, F. F. 2011. Educational Software Applied In Teaching and Assessing Physics In High Schools. Romanian Reports in Physics 63(2):577-586

Nani, K L \& Kusumah, Y S. 2015. The Effectiveness Ofict-Assisted Project- Based Learning in Enhancing Students' Statistical Communication Ability. International Journal of Education and Research 3(8):187-196

Nurohman, S. 2008. Pendekatan Project Based Learning Sebagai Upaya Internalisasi Scientific Method Bagi Mahasiswa Calon Guru Fisika. Yogyakarta: Universitas Negeri Yogyakarta.

Ogle, D. M. (1986). K-W-L: A Teaching Model That Develops Active Reading Of Expository Text. The Reading Teacher, 39(6), 564-570.

Richardson, F. (2012). Comprehension and Learning Strategy Before, During and After Reading Comprehension Strategy. Navan Education Centre, Athlumney, Navan. National Behaviour Support Service. Email: nbss@ecnavan.ie. Web: www.nbss.ie.

Sternberg, R. J., \& Lubart T. I. (1995). Defying The Crowd: Cultivating Creativity In A Culture Of Conformity. Free Press, New York.

Thomas, J. W. (2000). A Review of Research On Project-Based Learning. Supported By The Autodesk Foundation 111 McInnis ParkWay, San Rafael, California 94903. Bob Pearlman, Former President of The Autodesk Foundation, Commissioned This Study In The Year 2000. This Research Review and The Executive Summary are Available On http://www.bie.org/research/study/review_of_project_based_learning_2000.

Young, F. L. (1990). Knowledge-Based Systems For Idea Processing Support. New York, NY: ACM Press. Retrieved February 7, 2007, From Website

http://delivery.acm.org/10.1145/110000/109027/p27young.pdf?key1=109027\&key2=4259980711\&coll=GUID $\underline{E} \& \mathrm{dl}=\mathrm{GUID}$ E\&CFID $=10876020 \&$ CFTOKEN $=19836364$. 